\title{
Effect of the antral follicle count of Bos taurus $\times$ Bos indicus dairy cows on in vitro embryo production
}

\section{Efeito da contagem de folículos antrais de vacas Bos taurus $x$ Bos indicus com aptidão leiteira na produção in vitro de embriões}

\author{
Sheila Merlo Garcia ${ }^{1}$; Paula Alvares Lunardelli²; Kleber Luciano Ancioto \\ Eduardo Cardoso de Oliveira ${ }^{4}$; Larissa Zamparone Bergamo5; Amanda Fonseca \\ Zangirolamo $^{6}$; Marcelo Marcondes Seneda ${ }^{7 *}$
}

\section{Highlights:}

Antral follicle count (AFC) is an important reproductive characteristic in cattle.

AFC positively influenced the pregnancy rate in Girolando cow.

Girolando cow with high AFC had better IVEP success rates than those with low AFC.

\begin{abstract}
This study aimed to evaluate the potential of Girolando (Bos taurus $\times$ Bos indicus) cows with high and low antral follicle counts (AFC) for the in vitro production of bovine embryos (IVEP), as well as the pregnancy rates of the recipients of these embryos. Girolando cows (Bos taurus $\times$ Bos indicus) were classified as high and low AFC when they had 35-52 $(n=13)$ and 11-17 follicles $(n=15)$, respectively. All animals were subjected to repeated follicular aspiration [Ovum pick-up (OPU)] and subsequent IVEP sessions. The synchronization protocol of the recipients was performed on a random day of the estrous cycle (Day 0) with the implantation of progesterone, estradiol benzoate, and prostaglandin. The high AFC group had higher aspirated oocyte/OPU (42.6 \pm 5.2 vs. $14.6 \pm 1.9 ; \mathrm{p}<0.01)$ and cultured oocyte/OPU $(38.1 \pm 6.6 v s .12 .3 \pm 2.8 ; \mathrm{p}<0.01)$ averages as well as a higher blastocyst percentage on D7 $(23.0 \pm 1.0 \%$ vs. $18.4 \pm 1.5 \% ; \mathrm{p}<0.05)$ and higher pregnancy rate $(42.7 \pm 2.7 \%$ vs. $39.7 \pm 4.6 \% ; \mathrm{p}$ $<0.05)$ than the low AFC group. Thus, we can conclude that animals with high AFC had better IVEP success rates than animals with low AFC.
\end{abstract}

Key words: AFC. OPU. Embryo production. Bos taurus $\times$ Bos indicus.

1 Prof ${ }^{a}$ Dra , Universidade do Oeste Paulista, UNOESTE, Presidente Prudente, SP, Brasil. E-mail: sheila@unoeste.br

2 Dra , Programa de Pós-Graduação em Ciência Animal, Universidade Estadual de Londrina, UEL, Londrina, PR, Brasil. E-mail: palunardelli@hotmail.com

3 Gene Up, Presidente Prudente, SP, Brasil. E-mail: kleberancioto@geneup.com.br

4 M.e, Programa de Pós-Graduação em Matemática Aplicada e Computacional, Universidade Estadual Paulista "Júlio de Mesquita Filho", UNESP, Presidente Prudente, SP, Brasil. E-mail: edcarov@gmail.com

5 Discente do Curso de Doutorado do Programa de Pós-Graduação em Ciência Animal, UEL, Londrina, PR, Brasil. E-mail: larissabergamo1@hotmail.com

6 Pós-Dra , Programa de Pós-Graduação em Ciência Animal, UEL, Londrina, PR, Brasil. E-mail: amandafzvet@gmail.com

7 Prof. Dr., Programa de Pós-Graduação em Ciência Animal, Departamento de Clínicas Veterinárias, UEL, Londrina, PR, Brasil. E-mail: marcelo.seneda@uel.br

* Author for correspondence 


\section{Resumo}

Este estudo teve como objetivo avaliar o potencial de produção in vitro de embriões (PIVE) bovinos de vacas da raça Girolando (Bos taurus $x$ Bos indicus) com alta e baixa contagem de folículos antrais (CFA), bem como a taxa de prenhez nas receptoras destes embriões. As vacas da raça Girolando (Bos taurus $x$ Bos indicus) foram classificadas como de alta CFA quando apresentavam de 35 a 52 folículos $(\mathrm{n}=13)$ e baixa CFA, quando apresentavam de 11 a 17 folículos $(\mathrm{n}=15)$. Todos os animais foram submetidos a repetidas sessões de aspiração folicular (OPU) e subsequente PIVE. O protocolo de sincronização das receptoras foi realizado em um dia aleatório do ciclo estral (Dia 0) com implante de progesterona, benzoato de estradiol e prostaglandina. O grupo de alta CFA obteve uma maior média de oócitos aspirados / OPU (42,6 $\pm 5,2$ vs. 14,6 $\pm 1,9 ; \mathrm{p}<0,01)$; oócitos cultivados / OPU $(38,1 \pm 6,6 v s$. $12,3 \pm 2,8 ; \mathrm{p}<0,01)$; porcentagem de blastocistos em D7 (23,0 $\pm 1,0 \%$ vs. $18,4 \pm 1,5 \% ; \mathrm{p}<0,05)$ e taxa de prenhez $(42,7 \pm 2,7 \%$ vs. $39,7 \pm 4,6 \%$; $<<0,05)$ maiores quando comparado ao grupo de baixa CFA. Desta maneira, podemos concluir que os animais de alta CFA apresentaram melhores taxas de PIVE que os animais de baixa CFA.

Palavras-chave: CFA. OPU. Produção de embriões. Bos taurus $x$ Bos indicus.

\section{Introduction $^{8}$}

The increase in the use of animal reproduction biotechniques has contributed significantly to the accelerating genetic gain of the herd (Pontes et al., 2009). Techniques such as artificial insemination, fixed-time artificial insemination, superovulation, embryo transfer (ET), and in vitro embryo production (IVEP), associated with ultrasoundguided follicular aspiration [Ovum pick-up (OPU)], are crucial strategies that favor the multiplication and selection of animals with superior productive and genetic merits (Santos et al., 2016).

In dairy herds, biotechniques also facilitate the optimization of the use of semen of high economic value, the choice of the sex of embryos with sexed semen, and the selection of the best oocyte donors (Pontes et al., 2011). Crossbred cattle, such as Girolando cows (Gir $\times$ Holstein), became very popular on dairy farms owing to their high milk yield potential, inherited from Bos taurus animals, and their greater rusticity and follicular populations, inherited from Bos indicus animals (Pontes et al., 2010).
To further improve the results obtained by OPU and IVEP, researchers are looking for characteristics such as the ovarian antral follicle count (AFC) that will facilitate the selection of donors. However, some studies have obtained conflicting results regarding a possible relationship between the number of follicles and fertility (Mossa et al., 2012; Santos et al., 2013; Silva-Santos et al., 2014), and none evaluated this issue in crossed Bos taurus indicus $\times$ Bos taurus taurus animals with an aptitude for milk production.

Therefore, research questions aiming to clarify the relationship between AFC and fertility as well as the efficiency of reproductive biotechniques should be pursued.

The present study aimed to evaluate the potential of Girolando (Bos taurus $\times$ Bos indicus) cows with high and low AFC for the in vitro production of bovine embryos as well as the pregnancy rate of the recipients of these embryos.

\footnotetext{
8 Abbreviations: AFC: antral follicle count; Bl: blastocysts; COC: cumulus-oocyte complex; EB: estradiol benzoate; EC: estradiol cypionate; eCG: equine chorionic gonadotropin; ET: embryo transfer; IM: intramuscularly; IVEP: in vitro embryo production; IVF: in vitro fertilization; IVM: in vitro maturation; OPU: Ovum pick-up; P4: progesterone; PGF2 $\alpha$ : prostaglandin F2 $\alpha$; UNESP: Universidade Estadual Paulista.
} 


\section{Material and Methods}

\section{Location and animals}

The study was undertaken in the Presidente Prudente city region, on a dairy farm located west of the state of São Paulo, Brazil (22 ${ }^{\circ}$ ' 39' S, 51 23 ' 8 " W). The study was approved by the Ethics of Animal Use committee of Universidade Estadual Paulista (UNESP) (protocol CEUA 14/2013, UNESP-Campus Dracena, São Paulo).

Fifty multiparous Girolando cows (Bos taurus $\times$ Bos indicus), aged between 24 and 72 months, empty, in lactation, with body condition scores between 2.5 and 3.5 [on a scale of 1 to 5] (Lowman, Scott \& Somerville, 1976) were used. The animals weighed $525 \pm 25 \mathrm{~kg}$ on average, they were maintained on a continuous grazing system on Brachiaria decumbens pasture, and had ad libitum access to water and mineral salt.

\section{Antral follicle count}

The AFC was performed by ultrasound (Aloka SSD 500 transvaginal probe, $5 \mathrm{MHz}$; Japan) before each OPU session. After the evaluation, 28 donors were selected according to the normal distribution of the data and were classified as high AFC cows ( =13) when they had 35-52 follicles and low AFC cows $(n=15)$ when they had 11-17 follicles.

\section{Follicular aspiration}

Before each follicular aspiration guided by ultrasound (OPU), epidural anesthesia was performed with $3 \mathrm{~mL}$ of a $2 \%$ lidocaine hydrochloride $(2.5 \mathrm{~mL})$ and $0.1 \%$ xylazine hydrochloride $(0.5$ $\mathrm{mL}$ ) solution. Follicular aspiration was performed according to the protocol determined by Seneda, Esper, Garcia, Oliveira and Vantini (2001). Three to five OPU procedures were performed on each donor. Visible follicles larger than $2 \mathrm{~mm}$ in diameter were aspirated using an ultrasound device (in B mode) and a convex transducer fitted to an aspiration guide (Aloka SSD 500 transvaginal probe, $5 \mathrm{MHz}$;
Japan). Disposable $19 \mathrm{G}$ hypodermic needles were used to aspirate the follicles and were connected to an $80 \mathrm{mmHg}$ vacuum pump (VMAR-5100; Cook Veterinary Products, Australia).

Subsequently, all recovered oocytes $(n=2,694)$ were evaluated visually using a stereomicroscopic loupe (Nikon SMZ800N; Tokyo, Japan) and classified according to the morphological aspects of the cumulus-oocyte complexes (COCs), following the classification performed by Lonergan, Rizos, Ward and Boland (2001). The oocytes classified as atretic were discarded, and the rest were transported to the laboratory where they remained in a portable incubator (Minitub, Germany) at $39{ }^{\circ} \mathrm{C}$ for about 2 $h$, for maturation.

\section{In vitro embryo production}

For in vitro maturation (IVM), groups of a maximum of 25 oocytes were placed in drops of maturation medium containing TCM-199 medium (M-3769; Sigma Co., St. Louis, MO, USA) and were matured separately. The incubation was carried out in an oven (MCO-19AIC-UV; Panasonic, Japan) with $5 \% \mathrm{CO}_{2}$, at $39{ }^{\circ} \mathrm{C}$, with air and saturated humidity, for $24 \mathrm{~h}$.

For IVEP, 15 Holstein bulls (2-4 routines/bull) were used. The semen straws were thawed at 37 ${ }^{\circ} \mathrm{C}$ for $30 \mathrm{~s}$ and sperm selection was performed by the Percoll gradient technique (Parrish, Krogenaes, \& Susko-Parrish, 1995). The oocytes were coincubated with sperm in drops of TALP-FERT fertilization medium (added $20 \mathrm{mg} / \mathrm{mL}$ heparin and PHE, $2 \mathrm{mM}$ penicillin, $1 \mathrm{mM}$ hypotaurine, and 250 $\mathrm{mM}$ epinephrine). Sperm vigor and motility were assessed by optical microscopy (Eclipse E400; Nikon, Tokyo, Japan) and the sperm concentration was adjusted to obtain a final concentration of $1 \times$ $10^{6}$ viable sperm $/ 100 \mu L$. Subsequently, the plates were placed in the oven with $5 \% \mathrm{CO} 2$, at $39{ }^{\circ} \mathrm{C}$, with air and saturated humidity, for $20 \mathrm{~h}$. The fertilization day was considered as day zero (D0) of the protocol. 
In in vitro culture, the cumulus cells were removed by successive pipetting, and the possible zygotes were transferred to drops of SOF-M (modified) culture medium. On D3 and D5, feeding was performed, that is, $50 \%$ of the volume of the drops of culture was removed; later, fresh medium of the same volume was added. Embryo cultivation was carried out under the same conditions described for IVM and in vitro fertilization (IVF).

Embryonic development was evaluated seven days (D7) after fertilization and the embryos were classified according to their morphology, with only Grade I embryos in the morula and blastocyst stages destined for transfer (Sociedade Internacional de Transferência de Embriões, 1998).

\section{Synchronization of recipients}

The recipient cows were submitted to follicular wave synchronization and were all subjected to the same protocol. On a random day of the estrous cycle (D0), $2 \mathrm{mg}$ of estradiol benzoate (Estrogin ${ }^{\circledR}$; Biofarm, Jaboticabal, SP, Brazil) was administered intramuscularly (IM), and a $1.9 \mathrm{~g}$ progesterone releasing intravaginal device was inserted $\left(\mathrm{CIDR}^{\circledR}\right.$; Zoetis, Brazil). Upon implant removal (D8), the recipients received $500 \mu \mathrm{g}$ of prostaglandin F2 $\alpha$ (Ciosin ${ }^{\circledR}$; Intervet-Schering Plow, Brazil), 300 UI of equine chorionic gonadotropin (Novormon ${ }^{\circledR}$; Syntex SA, Argentina), and $1 \mathrm{mg}$ of estradiol cypionate IM $\left(\mathrm{ECP}^{\circledR}\right.$; Pfizer, Brazil). All recipients were evaluated by ultrasound (Aloka SSD 500 transvaginal probe, $5 \mathrm{MHz}$; Japan), and only those with corpus luteum were selected for fertilization. On D17, ETs were performed.

Follicular aspirations in donor cows were performed on D9 of the recipient synchronization protocol, while IVF was performed on D10 (Figure 1).

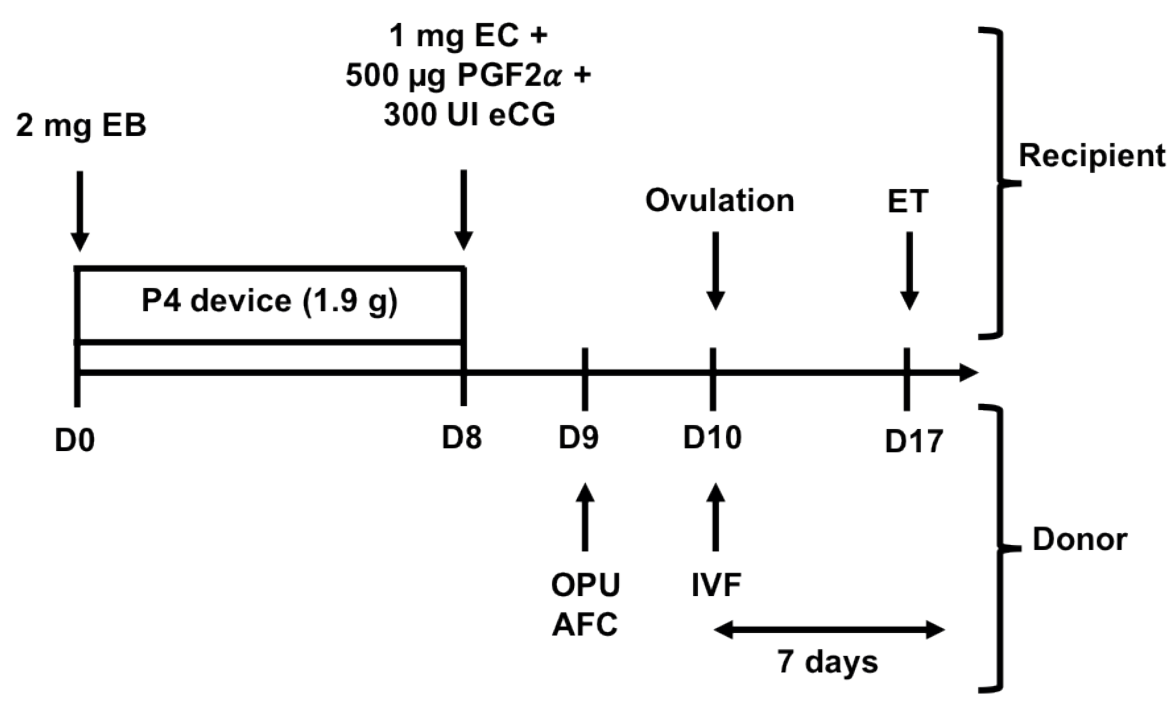

Figure 1. Hormonal protocol for follicular wave synchronization used in embryo recipient cows and donor aspiration chronological scheme.

EB: estradiol benzoate; P4: progesterone; PGF2 $\alpha$ : prostaglandin $\mathrm{F} 2 \alpha$; eCG: equine chorionic gonadotropin; EC: estradiol cypionate; OPU: Ovum pick-up; AFC: antral follicle count; IVF: in vitro fertilization; ET: embryo transfer. 
Embryo transfer and pregnancy diagnosis

Seven-day-old embryos were individually transferred into $0.25 \mathrm{~mL}$ straws and transported in an embryo carrier (WTA 100; Watanabe Tecnologia Aplicada Ltda, Cravinhos, SP, Brazil). The embryos were transferred to the recipients in a nonsurgical, transcervical manner, and pregnancy was determined by ultrasound evaluation (Aloka SSD 500 transvaginal probe, $5 \mathrm{MHz}$; Japan) 30 days after fertilization.

\section{Statistical analysis}

The data were considered non-parametric and were analyzed using the Kruskal-Wallis test for independent samples, using Dell Statistica 13.0. Values were considered significant when $\mathrm{p}<0.05$. To assess the differences between the groups (high and low AFC) we used the Chi-squared test, with the significance level set at 5\%. For the classification of donors in groups of high and low AFC, the Gaussian curve demonstrated the distribution of the AFC of the 50 donors, with its lower and upper limits used for the selection of females. Normality was assessed by the Shapiro-Wilk test, using Dell Statistica 13.0. The values were expressed as mean \pm standard deviation (SD), except for percentage values for which the measure of variation used was standard error (SE).

\section{Results}

Of the 45 aspirations performed on animals with high AFC and the 53 aspirations performed on animals with low AFC, a higher average number of oocytes aspirated by OPU and viable oocytes cultured by OPU was obtained in females in the high than in the low AFC group ( $\mathrm{p}=0.0001$; Table 1).

Table 1

Total and average number per follicular aspiration of aspirated and cultured oocytes from Girolando cows with high (35-52 follicles) and low antral follicle count (AFC) (11-17 follicles) guided by ultrasound [Ovum pick-up (OPU)]

\begin{tabular}{ccccccc}
\hline Group & $\begin{array}{c}\text { Animals } \\
(\mathrm{n})\end{array}$ & $\begin{array}{c}\text { Total } \\
\text { OPUs } \\
(\mathrm{n})\end{array}$ & $\begin{array}{c}\text { Aspirated } \\
\text { oocytes } \\
(\mathrm{n})\end{array}$ & $\begin{array}{c}\text { Average aspirated } \\
\text { oocytes/OPU } \\
\pm \mathrm{SD}\end{array}$ & $\begin{array}{c}\text { Viable cultured } \\
\text { oocytes } \\
(\mathrm{n})\end{array}$ & $\begin{array}{c}\text { Average viable } \\
\text { cultured Oocytes } / \\
\text { OPU } \pm \text { SD }\end{array}$ \\
\hline High AFC & 13 & 45 & 1,919 & $42.6 \pm 5.2$ & 1,716 & $38.1 \pm 6.6$ \\
Low AFC & 15 & 53 & 775 & $14.6 \pm 1.9$ & 652 & $12.3 \pm 2.8$ \\
P-value & - & - & - & 0.0001 & - & 0.0001 \\
\hline
\end{tabular}

Values were considered significant when $\mathrm{p}<0.05$.

The total and average numbers of blastocysts produced and transferred by OPU on D7 and the total and average numbers of pregnant OPU recipients, were higher in the high than in the low AFC group ( $\mathrm{p}=0.0001$; Table 2). 
Table 2

Total and average number per follicular aspiration of blastocysts (BI) produced on D7, blastocysts transferred from Girolando cows with high (35-52 follicles) and low (11-17 follicles) antral follicle counts (AFC), and total and average number of pregnancies per Ovum pick-up (OPU) in embryo recipients, guided by ultrasound (OPU)

\begin{tabular}{lcccccc}
\hline Group & $\begin{array}{c}\text { Total Bl } \\
\text { D7 (n) }\end{array}$ & $\begin{array}{c}\text { Average } \\
\text { Bl D7/OPU } \\
\pm \text { SD }\end{array}$ & $\begin{array}{c}\text { Bl } \\
\text { transferred (n) }\end{array}$ & $\begin{array}{c}\text { Average B1 } \\
\text { transferred/ } \\
\text { OPU } \pm \text { SD }\end{array}$ & $\begin{array}{c}\text { Pregnancy } \\
(\mathrm{n})\end{array}$ & $\begin{array}{c}\text { Average } \\
\text { pregnancy/OPU } \\
\pm \text { SD }\end{array}$ \\
\hline High AFC & 394 & $8.7 \pm 5.3$ & 328 & $7.3 \pm 4.4$ & 140 & $3.1 \pm 3.0$ \\
Low AFC & 120 & $2.3 \pm 2.1$ & 116 & $2.1 \pm 2.17$ & 46 & $0.9 \pm 1.1$ \\
P-value & - & 0.0001 & - & 0.0001 & - & 0.0001 \\
\hline
\end{tabular}

Values were considered significant when $\mathrm{p}<0.05$.

The percentage of blastocysts produced from the total number of cultured oocytes, as well as the percentage of pregnant recipients in relation to the number of embryos transferred, were also higher in the high than in the low AFC group ( $\mathrm{p}=0.037$ and $\mathrm{p}=0.048$; respectively; Table 3 ).

Table 3

Total number and percentage of blastocysts $(\mathrm{BI})$ on $\mathrm{D} 7$ in relation to the number of cultured oocytes, total number and percentage of $\mathrm{Bl}$ transferred in relation to the number of total $\mathrm{Bl}$ of Girolando cows with high (35-52 follicles) and low (11-17 follicles) antral follicle counts (AFC) on D7, and total number and percentage of pregnancies in embryo recipients

\begin{tabular}{lccccc}
\hline \multicolumn{1}{c}{ Group } & $\begin{array}{c}\text { Total Bl } \\
\mathrm{D} 7(\mathrm{n})\end{array}$ & $\begin{array}{c}\text { \% total Bl/ } \\
\text { cultured oocytes } \pm \mathrm{SE}\end{array}$ & $\begin{array}{c}\mathrm{Bl} \\
\text { transferred }(\mathrm{n})\end{array}$ & $\begin{array}{c}\text { Pregnancy } \\
(\mathrm{n})\end{array}$ & $\begin{array}{c}\text { \% pregnancy/Bl } \\
\text { transferred } \pm \mathrm{SE}\end{array}$ \\
\hline High AFC & 394 & $23.0 \pm 1.0$ & 328 & 140 & $42.7 \pm 2.7$ \\
Low AFC & 120 & $18.4 \pm 1.5$ & 116 & 46 & $39.7 \pm 4.6$ \\
P-value & - & 0.037 & - & - & 0.048 \\
\hline
\end{tabular}

\section{Discussion}

This is the first study that addressed the results of IVEP from crossbred Bos indicus $\times$ Bos taurus cattle with dairy aptitude according to their antral follicle count. The results of this study showed that females with a high AFC (35-52 follicles) were more efficient than females with a low AFC (11-17 follicles) in all evaluated parameters.

The percentage of total blastocysts in relation to cultured oocytes was higher in females with high $\operatorname{AFC}(23.0 \pm 1.0 \%)$ than in those with low AFC $(18.4$ $\pm 1.5 \%$ ). This result along with the highest mean of aspirated oocytes/OPU in the high than in the low AFC group (42.6 \pm 5.2 and $14.6 \pm 1.9$, respectively; $p<0.01$ ), corroborate the results obtained by Silva-
Santos et al. (2014) who evaluated crossbred beef cattle. In that study, averages of $36.9 \pm 13.7$ and $5.8 \pm 3.4$ oocytes were recovered from the high and low AFC animal groups, respectively, which belonged to the Braford breed (3/8 Bos indicus and $5 / 8$ Bos taurus). The authors did not observe any differences between the groups, probably owing to a smaller sample size $(n=122$ embryos in the high AFC group; $n=11$ embryos in the low AFC group). However, the high $(16.5 \%)$ to low $(9.5 \%)$ AFC group blastocyst rate ratio (1.7) was very close to the 1.3 ratio found in the present study $(23.0 \pm 1.0 \%$ and $18.4 \pm 1.5 \%$ blastocyst rates, respectively).

Similar results were obtained from a European study on Bos taurus females, in which the group 
classified as low AFC had a lower number of embryos compared to the high AFC group [1.3 and 4.9 embryos, respectively] (Ireland et al., 2007). Likewise, in Brazil, in a study on Nelore females (n $=66$ ) classified as high ( $>40$ follicles), intermediate (18-25 follicles), or low AFC ( $<7$ follicles), 42\%, $32 \%$, and $13 \%$ blastocyst rates were obtained, respectively, after OPU and IVEP [p $<0.05]$ (Santos et al., 2016), thus confirming the quantitative advantages of the high AFC group.

In this context, Monteiro et al. (2017) observed that in Bos indicus females with high (>15) COC counts that were recovered after 12 consecutive OPU sessions, the number of blastocysts produced per OPU session was not affected. Additionally, donors with greater $\mathrm{COC}$ numbers that were recovered at the beginning of the program, had increased blastocyst numbers per each OPU and IVEP session, indicating an advantage of aspirating females in this group in terms of obtaining better results in the production of embryos. However, in another study on Bos indicus cattle, no differences were observed in the blastocyst rates of cows classified in high ( $>$ 92 follicles), intermediate (46-76 follicles), or low AFC ( $<31$ follicles) groups $(40 \%, 36 \%$, and $38 \%$, respectively) (Rosa et al., 2018). Thus, it should be noted that the variety of methods used in different studies for classifying females according to their $\mathrm{AFC}$, is a critical point that must be considered and discussed.

Additionally, although the pregnancy rate is a parameter of great importance to evaluate the efficiency of reproductive biotechniques, in the present study, the effects of the bull and the recipient were not evaluated. Thus, it was not possible to associate this parameter with AFC, although a higher pregnancy rate was observed in the high than in the low AFC group $(42.7 \pm 2.7 \% v s .39 .7 \pm 4.6 \%$, respectively; $\mathrm{p}<0.05)$.

In summary, the results of this study showed that crossbred Girolando females (Bos taurus $\times$ Bos indicus) with a higher AFC, had the highest potential for in vitro embryonic development, thus reinforcing the importance of evaluating AFC in OPU-IVEP programs.

\section{Conclusions}

Crossbred Girolando females (Bos taurus $\times$ Bos indicus) with high AFC, had better IVEP success rates. Additionally, the selection of high AFC oocyte donors of the Girolando breed, using ultrasound evaluation, proved to be a precise method to estimate in vitro embryo production.

\section{References}

Ireland, J. J., Ward, F., Jimenez-Krassel, F., Ireland, J. L. H., Smith, G. W., Lonergan, P., \& Evans, A. C. O. (2007). Follicle numbers are highly repeatable within individual animals but are inversely correlated with FSH concentrations and the proportion of good-quality embryos after ovarian stimulation in cattle. Human Reproduction, 22(6), 1687-1695. doi: 10.1093/humrep/dem071

Lonergan, P., Rizos, D., Ward, F., \& Boland, M. P. (2001). Factors influencing oocyte and embryo quality in cattle. Reproduction Nutrition Development, 41(5), 427-437. doi: 10.1051/rnd:2001142

Lowman, B. G. N., Scott, N. A., \& Somerville, S. H. (1976). Condition scoring of cattle. Edinburgh: The Edinburgh School of Agriculture. (East of Scotland College of Agriculture. Bulletin.

Monteiro, F. M., Batista, E. O. S., Vieira, L. M., Bayeux, B. M., Accorsi, M., Campanholi, S. P.,... Baruselli, P. S. (2017). Beef donor cows with high number of retrieved $\mathrm{COC}$ produce more in vitro embryos compared with cows with low number of COC after repeated ovum pick-up sessions. Theriogenology, 90, 54-58. doi: 10.1016/j.theriogenology.2016.11.002

Mossa, F., Walsh, S. W., Butler, S. T., Berry, D. P., Carter, F., Lonergan, P.,... Evans, A. C. O. (2012). Low numbers of ovarian follicles $\geq 3 \mathrm{~mm}$ in diameter are associated with low fertility indairy cows. Journal of Dairy Science, 95(5), 2355-2361. doi: 10.3168/ jds.2011-4325

Parrish, J. J., Krogenaes, A., \& Susko-Parrish, J. L. (1995). Effect of bovine sperm separation by either swim-upor Percoll method on success of in vitro fertilization and early embryonic development. Theriogenology, 44(6), 859-869. doi: 10.1016/0093$691 x(95) 00271-9$ 
Pontes, J. H. F., Melo Sterza, F. A., Basso, A. C., Ferreira, C. R., Sanches, B. V., Rubin, K. C. P., \& Seneda, M. M. (2011). Ovum pick up, in vitro embryo production, and pregnancy rates from a large-scale commercial program using Nelore cattle (Bos indicus) donors. Theriogenology, 75(9), 1640-1646. doi: 10.1016/j.theriogenology.2010.12.026

Pontes, J. H. F., Nonato, I., Jr., Sanches, B. V., Ereno, J. C., Jr., Uvo, S., Barreiros, T. R. R.,... Seneda, M. M. (2009). Comparison of embryo yield and pregnancy rate between in vivo and in vitro methods in the same Nelore (Bos indicus) donor cows. Theriogenology, 71(4), 690-697. doi: 10.1016/j. theriogenology. 2008.09 .031

Pontes, J. H. F., Silva, K. C. F., Basso, A. C., Rigo, A. G., Santos, G. M. G., Sanches, B. V.,... Seneda, M. M. (2010). Large-scale in vitro embryo production and pregnancy rates from Bos taurus, Bos indicus, and indicus-taurus dairy cows using sexed sperm. Theriogenology, 74(8), 1349-1355. doi: 10.1016/j. theriogenology.2010.06.004

Rosa, C. O., Marinho, L., Rosa, P. da, Cesaro, M. P. de, Lunardelli, P. A., Silva-Santos, K. C.,... Seneda, M. M. (2018). Molecular characteristics of granulosa and cumulus cells and oocyte competence in Nelore cows with low and high numbers of antral follicles. Reproduction in Domestic Animals, 53(4), 921-929. doi: 10.1111/rda.13189
Santos, G. M. G., Silva-Santos, K. C., Barreiros, T. R. R., Blaschi, W., Morotti, F., Silva, C. B.,... Seneda, M. M. (2013). Conception rates following FTAI of Nelore cows (Bos indicus) with high, intermediate and low numbers of antral follicles. Animal Reproduction, 10(3), 451-451.

Santos, G. M. G., Silva-Santos, K. C., Barreiros, T. R. R., Morotti, F., Sanches, B. V., Moraes, F. L. Z.,... Seneda, M. M. (2016). High numbers of antral follicles are positively associated with in vitro embryo production but not the conception rate for FTAI in Nelore cattle. Animal Reproduction Science, 165, 17-21. doi: 10.1016/j.anireprosci.2015.11.024

Seneda, M. M., Esper, C. R., Garcia, J. M., Oliveira, J. A., \& Vantini, R. (2001). Relationship between follicle size and ultrasound-guided transvaginal oocyte recovery. Animal Reproduction Science, 67(1-2), 3743. doi: $10.1016 / \mathrm{S} 0378-4320(01) 00113-0$

Silva-Santos, K. C., Santos, G. M., Koetz, C., Jr., Morotti, F., Siloto, L. S., Marcantonio, T. N.,... Seneda, M. M. (2014). Antral follicle populations and embryo production - in vitro and in vivo - of Bos indicus-taurus donors from weaning to yearling ages. Reproduction in Domestic Animals, 49(2), 228232. doi: $10.1111 /$ rda. 12255

Sociedade Internacional de Transferência de Embriões (1998). Manual da sociedade internacional de transferência de embriões (3a ed.). Illinois. 